насчитывают по 17,6\% и наиболее продуктивной характеристикой при вторичном топонаречении становится культурно-историческое наследие местности.

В действительности, очень интересен и сложен вопрос самого процесса имянаречения, а, в особенности, вторичного имянаречения географических объектов. Исследования такого рода позволяют нам задуматься о том, как именно он происходит с когнитивной точки зрения; почему из огромного количества характерных особенностей любого географического объекта, номинатор выбирает именно данную характеристику; как появившееся прозвище становится устойчивым и широко известным в пределах города, региона, страны, мира; почему одни объекты имеют много прозвищ, а другие лишь одно или несколько и т.д.

Следует заключить, что суть прозвищной номинации заключается в формировании устойчивых представлений об объекте номинации. Данное исследование частотности семантической базы топономинаций позволяет указать на значительное преобладание исторического, культурного и социально-политического компонента в топопрозвище, отражая, тем самым, наиболее значимую сферу общественной жизни человека, зафиксированную в языке.

$$
* * *
$$

1. Варуха И.В., Шамсутдинова Ю.Х. Структура семантического поля эмотивов страха в английском языке // Доклады Башкирского университета, 2020. - Том 5. №3. - С. 207-210.

2. Бондалетов В.Д. Русская ономастика. - М.: Наука, 1983. - 224 с.

3. Розенталь Д.Э., Теленкова М.А. Словарь-справочник лингвистических терминов. - М., 2001. - 624

4. Рябцова Н.И. Адъективация существительных как способ экспрессивного словообразования во французском языке // Коммуникативные единицы в свете современных научных парадигм. Сборник материалов Всероссийской научно-практической конференции с международным участием. Уфа: РИЦ БашГУ, 2019. Т.2. С. 218-221.

5. Уразметова А.В. Топонимическая система США: первичная и вторичная номинация: Монография. - М.: Флинта: Наука, 2017. - 188 с.

\title{
Уткина Е.В. \\ Портрет Ольги Лариной в романе А.С. Пушкина «Евгений Онегин» и стиховые средства его создания
}

ВО «Оренбургский государственный педагогический университет» (Россия, Оренбург)

doi: 10.18411/lj-04-2021-198

\section{Аннотация}

В статье в русле актуального сегодня направления в изучении функциональных особенностей поэтического портрета, его возможностей решать авторские задачи исследуется изображение Ольги Лариной. Автор проводит анализ всех портретных характеристик героини и обращает внимание на чаще употребляемые общие характеристики внешности и поведения, активно используемые сравнения (в том числе скрытые), цветовые характеристики, присутствие авторской оценки (в том числе авторской иронии). Особое внимание уделяется взаимодействию портретообразующих средств со стиховыми (рифмами, стихотворным переносом, особенностями ритмического движения (спондеями и пиррихиями), которые позволяют автору показать не только внешние черты облика Ольги, но и ее душевные качества, что, безусловно, способствует более глубокому понимаю места и роли данного образа в идейном контексте произведения.

Ключевые слова: портрет, поэтический портрет, портретообразующие средства, стиховые средства, рифма, стихотворный перенос, особенности ритмического движения. 


\section{Abstract}

In the article, in line with the current trend in the study of the functional features of the poetic portrait, its ability to solve the author's problems, the image of Olga Larina is studied. The author analyzes all the portrait characteristics of the heroine and draws attention to the most commonly used general characteristics of appearance and behavior, actively used comparisons (including hidden ones), color characteristics, the presence of the author's assessment (including the author's irony). Special attention is paid to the interaction of portrait-forming means with verse (rhymes, poetic transfer, features of rhythmic movement (spondeiae and pyrrhichiae), which allow the author to show not only the external features of Olga's appearance, but also her spiritual qualities, which, of course, contributes to a deeper understanding of the place and role of this image in the ideological context of the work.

Keywords: portrait, poetic portrait, portrait-forming means, poetic means, rhyme, poetic transfer, features of rhythmic movement.

Современное литературоведение в последнее время все чаще обращается к исследованию портрета, его функционированию и развитию прежде всего в лирическом тексте [1, 3], намечаются новые перспективы его изучения. Актуальным сегодня является рассмотрение поэтического портрета не только в его тесной взаимосвязи с живописным, но также взгляд на него как на предмет и цель изображения и авторского мировоззрения в их единстве $[2,4]$. Наше исследование проводится в русле такого подхода.

Поэтическое творчество А.С. Пушкина представляет множество примеров сгущенных и эмоционально содержательных портретных изображений. Пушкин стремится создать целостное изображение, что находит отражение в способах и приемах. В этой связи, наиболее сложными по воплощению и реализации авторских задач, являются изображения героев романа «Евгений Онегин». Мы уже обращались к исследованию портретов Евгения и Татьяны $[5,6]$, акцентируя внимание на участии стиховых средств в их создании. Объектом пристального интереса в данной статье стало внешнее изображение Ольги Лариной.

Цель данной статьи заключается в анализе портрета Ольги Лариной, в выявлении степени участия стиховых средств (рифм, стихотворных переносов, особенностей ритмического движения (спондеев и пиррихиев) в его создании.

В тексте романа нами выявлено 16 примеров портретных характеристик Ольги. Создавая облик младшей сестры Татьяны, Пушкин, прежде всего, обращается к общим чертам ее внешности и поведения: он говорит о присущей ей естественности, невинном обаянии [2, XXI], всегдашней скромности и жизнерадостности, податливости натуры, о голубых «как небо» глазах, льняных локонах, легком стане [2, XXIII]. Bce, ее движения, голос, поведение, их резвость и беспечность (6, XIII) являют в ней кокетку, ветреного ребенка $[5, \mathrm{XLV}]$ с резвой душой [6, XIV].

Сообщая читателю детали ее внешнего портрета, автор не стремится к глубоким и емким характеристикам. Примером служит описание лица: оно может быть «круглымм», «краснылм» [3, V], «самолюбивым» [5, XLIII. XLIV]. Пушкин заведомо «обманывает» читателя, ожидающего от героини в момент совершения таинства венчания внутреннего трепета и стыдливости, но стыдливость оказывается «внешней», «поникшая голова» скрывает «огонь» в очах, а на устах «легкую» улыбку [7, VIII].

Проведенные нами исследования портретного изображения Ольги и ранее портретов главных героев романа Онегина и Татьяны $[5,6]$ позволили выявить следующую особенность. Так, в создании портретного облика каждого из этих персонажей Пушкин использовал семантическую группу слов очи - взор - глаза взгляд, и, если в изображении Онегина в этой группе доминировало слово взор [6, с. 357], в изображении Татьяны слово очи [5, с. 336], то, в портрете Ольги автор 
предпочитает употреблять слово глаза, значительно упрощая его характеристику. Так, ее глаза голубые, «как небо» [2, XXIII], ими она «ищет» Ленского [6, I]; взгляд Ольги обладает ясностию [6, XIV], в ее потупленных очах скрывается огонь [7, VIII],

Мимических и жестовых проявлений в портрете Ольги почти не находим, характер имеющихся жестов прост: она зевает и ищет глазами своего возлюбленного [6, I], на ее устах может сквозить «легкая» улыбка [7, VIII].

Однако, создавая облик героини, Пушкин использует большое количество сравнений: она весела, как утро, простодушна, «как жизнь поэта», мила, «как поцелуй любви» $[2, \mathrm{XXIII}]$, легка и подвижна как ласточка [5, XXI], подвижна настолько, что прыгнула с крыльца как ветреная надежда [6, ХІІІ] - здесь уже появляется емкий оценочный эпитет, которому ранее предшествует другой: «Кругла, красна лицом она, / Как эта глупая луна» [3, V]. В большинстве своем эти сравнения содержат оценку («ветреньй ребенок», «резвою душой», «звонкий голос», «с ульббкой легкой»).

В создании портрета Ольги участвуют и скрытые сравнения с портретом Татьяны. Если Ольга весела, подвижна, простодушна, то Татьяна молчалива, дика, мечтательна, печальна, трепетна, полна «гордости небесной». И если лицо Ольги автор сравнивает с глупой луной, то Татьяна, «как величавая луна» блестит меж светскими дамами [7, LII].

Пушкин прямо сообщает читателю и о своей оценке портрета Ольги: он «очень мил», но тут же - «Но надоел он мне безмерно» [2, XXIII]. Авторская ирония проникает и в диалог двух героев. Так, к характеристике фигуры героини Онегиным, ее «nохорошевшим» плечам и груди восторженным Ленским добавляется «Что за душа!» [4, XLVIII]. Онегин как бы подводит итог авторской оценке: в ее чертах «жизни нет» $[3, \mathrm{~V}]$.

Исследуя роль и участие стиховых средств в создании портрета Ольги Лариной, мы выявили 13 рифмопар (11 смежных и 2 опоясывающих).

Чаще они связаны с общим портретом героини (7 рифмопар): ее фигурой, лицом (например, стан - роман, грудь - когда-нибудь, душою - головою, лицом она - луна, очах - устах, досада- взгляда).

Чуть реже с ее внешними движениями (например, играет - влетает, играть иеловать, зевала-искала).

Несколько рифмопар представляют характерный при создании портретов в романе акцент на цвет. В изображении Ольги мы наблюдаем присутствие красного цвета и его оттенков (в частности, алого). Например, «красна лицом» или «Авроры северной алей». Может присутствовать и не прямое указание на цвет, так характеристика румянца («Румянеи ярче») подчеркивает самолюбие героини («B ее лице самолюбивом»).

Такое ритмико-синтаксическое явление, как стихотворный перенос, в создании портрета Ольги почти не используется Пушкиным. Нами найдено только два случая. Между тем, создавая портреты главных героев, автор его задействовал довольно часто (14 случаев в создании портрета Онегина и 17 случаев в создании портрета Татьяны) [6, c. 358], [5, с. 336]. Стихотворный перенос помогал ему в передаче сложного, насыщенного и меняющегося эмоционального состояния Онегина и Татьяны. Портретное изображение Ольги бедно душевными откликами. Это подтверждает и найденный пример. Пушкин использует перенос лишь для передачи ее самолюбия, проявившегося в ответ на ухаживания Онегина. Но и здесь самолюбию героини противопоставляется «живое» чувство ревности Ленского.

И руку жмет - и запылал

В ее лице самолюбивом

Румянец ярче. Ленский мой

Все видел: вспыхнул сам не свой; [5, XLIII. XLIV] 
Реже, чем в создании портретов других действующих лиц (Евгения, Татьяны), в обрисовке облика Ольги встречаются пиррихии. Они связаны с внешними характеристиками ее портрета: цветом глаз, движеньями, голосом, фигурой («легким станом») [2, XXIII] или его деталями: «Развитым локоном играть / Иль край одежды целовать» $[4, \mathrm{XXV}]$; могут касаться поведения, фиксирующего внутреннее состояние: «Ольга к ней, / Авроры северной алей / И легче ласточки влетает...» [5, XXI], «За ним и Оленька зевала / Глазами Ленского искала...» [6, I], «Пред этой ясностию взгляда, / Пред этой нежной простой» [6, XIV], «Стоит с поникшей головою, / С огнем в потупленных очах» [7, VIII].

Наличие спондеев анализ портретного изображения Ольги не выявил.

Таким образом, работая над созданием портрета Ольги Лариной, Пушкин не стремится к воплощению глубокого психологического образа. Изображение сестры Татьяны бедно душевными проявлениями, поэтому основное внимание уделяется деталям внешности и поведению героини. Для чего часто используются сравнения, оценочные эпитеты. Мимика и жесты почти не участвуют и предельно упрощены. Портрет вбирает и пушкинскую ироничную характеристику, им вовлекаются и цветовые решения. Здесь, так же, как и в создании портретных изображений главных героев, активно используются стиховые средства. Чаще это рифма, она участвует в обрисовке внешности (общего портрета, лица, фигуры), реже - стихотворный перенос и пиррихии. К последним автор прибегает для выражения ее внутреннего облика или состояния (самолюбия, скуки, ясности взгляда, лукавости). Таким образом, портретное изображение Ольги Лариной соответствует чертам отвлеченного портрета.

$$
* * *
$$

1. Башкеева, В.В. От живописного портрета к литературному. Русская поэзия и проза конца XVIII первой трети XIX века. - Улан-Удэ: Издательство Бурятского госуниверситета. - 1999. - 270 с.

2. Дмитриевская, Л.Н. Портрет и пейзаж в русской прозе: традиция и художественные эксперименты. - Москва - Ярославль: Литера, 2014. - 200 с.

3. Колосова, С.Н. Типология и поэтика портрета в русской лирической поэзии: дисс. ... д-ра филол. наук / С.Н. Колосова. - Москва, 2012. - 384 с.

4. Морозова, А.В. К вопросу о стиховых средствах создания словесного портрета (на материале поэм А.С. Пушкина) // Вестник ОГУ. - 2006. - № 6. - С. 14-18.

5. Уткина Е.В. Портретное изображение Татьяны Лариной в романе А.С. Пушкина «Евгений Онегин» и стиховые средства его создания // Мир науки, культуры, образования. 2020; № 5 (84): 335-337.

6. Уткина Е.В. Портрет Онегина в романе А.С. Пушкина «Евгений Онегин» и стиховые средства его создания // Филологические науки. Вопросы теории и практики. 2019; Т. 12, Выпуск 4: 355-359.

\section{Шалифова О.Н., Шнейдман Е.Л. \\ Английские заимствования во французском языке: история и современность}

Самарский государственный сочиально-педагогический университет (Россия, Самара)

doi: 10.18411/lj-04-2021-199

\section{Аннотация}

Статья посвящена изучению процесса лексических заимствований из английского языка во французский в разные исторические периоды. Описываются основные факторы, которые оказали влияние на формирование так называемого «franglais», приведены примеры англицизмов, относящихся к различным сферам общественной жизни, в результате анализа лексикографических источников устанавливается общее количество англицизмов во французском языке. Особое внимание уделяется проникновению англицизмов в сферу общественного питания современной Франции. 